\title{
Risk analysis and management on Public Private Partnership Projects (PPP) in Serbia
}

\author{
Simo Suđić \\ College for Civil Engineering \\ and Geodesy, Belgrade - \\ Management and \\ Organisation Department \\ sudic@codest.ru
}

\author{
Goran Ćirović \\ College for Civil Engineering \\ and Geodesy, Belgrade - \\ Management and \\ Organisation Department \\ cirovic@sezampro.rs
}

\author{
Snežana Mitrović \\ University of Banja Luka, \\ Bosnia and Hercegovina, \\ Faculty of Architecture \\ and Civil Engineering \\ mitrozs@sezampro.rs
}

DOI 10.5592/otmcj.2013.1.6 Research paper

\section{Keywords}

Public private partnership

(PPP) projects, Risk analyze and management, Project financing, infrastructure projects
INFRASTRUCTURE PROJECTS ARE GOING THROUGH A LOT OF DIFFICULTIES, MOSTLY CONNECTED WITH NON STANDARD ESTABLISHED FinANCING in SOUTH EAStern EURope countries. During and after transition period, undeveloped, insufficient but before all obsolete infrastructure in Serbia became a essential problem for further development of main economic resources (transportation, agriculture, mining, tourism etc.). Infrastructure network is necessity for the development of different sectors (energetic, agriculture, industry, commerce etc.). Domestic regulation is not clear in allowing project financing through Public Private Partnership (PPP) model, which is great opportunity for opening new projects and finishing many projects with on hold status. The main problem in decision making and starting financing projects in that model is too many risks on the market, which endanger projects from very beginning, especially in initiation phase so many investors decide to leave projects in very early phases. The analysis of potential risk elements, throughout the processes from bidding to operational infrastructure projects, is one of the most important elements to maximizing profit and functionality, and properly develop country infrastructure, while minimalizing potential difficulties that may arise. Much of the risk of a PPP project comes from the complexity of financing, taxation, law regulatory, aquired technical documentation and construction process involved in a major infrastructure venture. Main risks, their analyze and management on infrastructure projects are explained in this paper. After risk analyze, risk management tools are presented, together with method of managing risks on PPP projects in Serbia. 


\section{INTRODUCTION -}

\section{Background of public/private} partnership projects

In its widest sense a public/private partnership (PPP) may be defined as "a long term relationship between public and private sectors that has the purpose of producing public services and infrastructure" (Zitron, 2004). Public/ private partnerships bring public and private sectors together in long term contracts. PPPs (public/private partnership) encompass voluntary agreements and understandings, servicelevel agreements, outsourcing and private finance initiative. A PPP projects therefore usually involves the delivery of a traditional public sector service and can encompass a wide range of options. General idea of that concept is to mobilize to use private sector capital to generate economic development, and to deliver value for money to the public sector, and the higher costs of private sector financing and the level of returns demanded by the private sector investors must be outweighed by lower whole-life costs and increased risk transfer. One of the main goals is to develop infrastructure projects including roads, hospitals and schools, without the response to the limited capital of the public sector and utilizing superior cash and project management capacity of the private sector.

As the infrastructure has great impact on the development of whole economic of the country, the main reason for the delayed development of Serbian economy is many unfinished infrastructure projects. Financing that projects has largely developed from institutions like as European Investment Bank (EIB) and the European Bank for Reconstruction and Development (EBRD), but disproportion of demand and availability of financing obtrude using new way of financing projects. More than ten years ago EIB has signaled its intention to get involved in more public-private-partnerships (PPP). (Marray, 2001).
Also, it is observed that maintenance of the infrastructure has very high costs as low quality of construction and as whole live cost was not calculated during realization of investments. Current experience in Serbia construction sector lead to conclusion that local companies have good experience in technical field, but not much experience in contract administration, and that is the main reason for disputes and contract breaches on international projects.

In April 2004, in its Green Paper On-Public-Private Partnership and Community Law on Public Contracts and Concessions, the European Commission used the term 'phenomenon' to describe the spread of public/private partnership (PPPs) across Europe. That's the main reason why these type of procurement of civil engineering and infrastructure projects start to be reviewed in a countries which are in the process of joining the European Union like Serbia, Bosnia and Herzegovina etc. Traditional procurement process is less complicated and cheaper than procurement of public/private partnership projects, as the procedure is demanding and potential project members are not experienced in these procedures. However, several laws allow certain types of PPPs, Serbian law does not define and regulate PPPs in general. Serbian Concession Law from 2003 covers concessions and BOT arrangements, but PPPs model of financial arrangements is not clearly defined.

The main weaknesses in government procurement systems in Serbia are:

organization;

process;

- people and skills;

measurement;

- contribution of the central government.

Accordingly, PPP can be defined as agreements where public sectors bodies enter into long-term contractual agreements with private sector entities for the construction or management of public sector infrastructure facilities by the private sector entity, or the provision of services (using infrastructure facilities) by the private sector entity to the community on behalf of a public sector entity. They can make many forms and may incorporate some or all of the following features (Peirson G., McBride P, 1996):

- The public sector entity transfers facilities controlled by it to private sector entity (with or without payment in return) usually for the term of the arrangement;

- The private sector entity builds, extends or renovates a facility;

- The public sector entity specifies the operating features of the facility;

- Services are provided by the private sector entity using the facility for the defined period of time (usually with restrictions on operations and pricing; and

- The private sector entity agrees to transfer the facility to the public sector (with or without payment) at the end of the arrangement.

- As Serbia government have been motivated into entering into PPP arrangements to improve lack of infrastructure and by the desire to reduce debt, the other benefit is to share financial risk between public and private sector bodies, and in the next chapter will be examined these risks.

\section{Main risks on public/private partnership projects}

The main risks of the PPP projects comes from the complexity of the arrangements between public and private sector bodies. As the organizational structures of Serbian public sector bodies are very complex (due to very poor privatization process, insufficient modernization, involvement and implementation of international standards etc.), it is very important to approve organizational structure of the project before operational phase. In project organization structure all positions should be covered to obtain 
full contact with project environment and to minimize risks and difficulties in delivery.

Issues such a political leadership, bureaucratic resistance to change and corruption often create disinterest and disillusion in the private sector. Critical success factor (CSFs) according to (Bing et al., 2005) in UK can be grouped into five principal factors and be interpreted as follows:

a. effective procurement;

b. project implementability;

c. government guarantee;

d. favorable economic conditions;

e. available financial market.

It is very interesting that these critical success factors could be implemented for projects in Serbia also.

In Serbia during the previous period many land disputes have arises due to unfinished process of restitution. Political agitation and disruptions create unfavorable climate for the private sector to commit significant resources in order to participate with government in respect of long-term projects.

The other risks are the complexity of the arrangements itself in terms of documentation, financing, taxation, technical details, subcontracting, project delivery, etc. Infrastructure projects are long term projects, and the nature of the risks alters over the duration of the projects.

PPP tenders might fail due to inexperience and lack of technical knowledge on the part of the bureaucrats to design an appropriate PPP process, political interference, a poor design tender documentation and tender evaluation methodology or failure to negotiate a commercial rigorous contracting structure. Serbian government have opened many agencies which have not enough qualified and experienced specialists to proceed PPP procedures. The balance between the commercial realities and the bureaucrats' desire to impose regulatory and institutional framework that might otherwise destroy an deal. Also civil protest could be risky for that type of contracts. Civil protest may be result of lack of stakeholder consultation before designing the project structure, and lack of appreciation of the political situation by bureaucrats when structuring the environmental/ commercial/cost recovery aspects of the project.

Construction phase mostly open many different risks from those during the preparation and operational phase. The most important risks in that part of the project are insufficient results from geotechnical surveys, bad contractors, claims, increased budget, bad quality of works etc.

From the viewpoint of public procurer, the main goal is to ensure that the money has been spent economically, efficiently and effectively, and to find optimal solution to deliver project on time. Government seeks to optimize private sector financing in the provision of public sector infrastructure and service and to achieve value for money. For the public funds it is very important to comprehend value for money concept, and the most important is to transfer risks to the private partners who have responsibility for the design, construction and operational phases. In some cases, the emphasis on risk transfer can be misleading as value-for-money requires equitable allocation of risk between the public and private sector partners, and they may be an inherent conflict between the public sector's need to demonstrate the valuefor-money versus the private sector's need for robust revenue streams to support the financing arrangements (Grimsey D, Graham R, 1997).

The contractual provisions in PPP contracts are complex, and should include among other requirements (technical, financial, etc.) following:

Requirements for performance bonds;

> Insurance requirements;

Delay provisions;

- Force majeure;

Government action;
Private sector warranties;

Change in the law;

Variations;

Termination;

Indemnification;

Intellectual property;

> Claims;

- Financial security;

Dispute resolution;

> Partnership management;

- Compliance with all laws;

Personal and conditions precedent.

What are the main risks of civil engineering and infrastructure projects? At least nine risks face any infrastructure project (Chapman CB \& Ward SC., 1997)

$\checkmark$ Technical risk, due to engineering and design failures;

- Construction risk, because of faulty construction techniques and cost escalation and delays in construction;

Operating risks, due to higher operating costs and maintenance costs;

- Revenue risk; e.g. due to traffic shortfall or failure to extract resources, the volatility of prices and demand for products and services sold (e.g. minerals, office space etc.) leading to revenue deficiency;

- Financial risks arising from inadequacy hedging of revenue streams and financing costs;

- Force majeure risk, involving warned other calamities and act of God;

- Regulatory/Political risks, due to legal changes and unsupportive government policies;

- Environmental risks, because of adverse environmental impacts and hazards;

> Project default, due to failure of the project from a combination of any of the above.

From the experience of the authors top five risks facing the PPP projects in Serbia are:

- Government bureaucrats and complex procedures, due to high financial expectation of public sector;

- Many problems and disputes from the ownership, especially of land, 
due to bad privatization process and unfinished restitution;

Often changes in local authorities as well as government;

> Financial problem in construction sector, and unpredictable performance of construction companies;

Operational and maintenance risk, due to unpredictable revenue as different social programs of government.

\section{Proposed method for risk} management on ppp projects

General idea of risk management process frame is to identify all main risks and to calculate time and cost contingency of the project, based in these risks. This data will help the decision makers to define strategy of the project in the planning phase. In figure 1 it is presented first part of the risk register table.

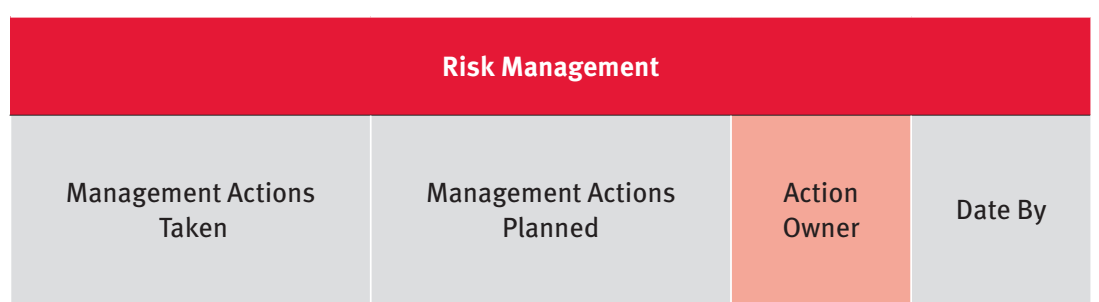

Figure 2 Risk Management Procedure

tional costs in a project). Transferring risks means to shift risks from some participants in the project to other participants, assuming that they will manage that risk easier, and that the risk level will be lower in this case. Avoidance of risks means the implementation of managerial action which does not bring the project into the zone of a specific risk.

Risk management involves eliminating or reducing the risk level implementing managerial actions. Planned managerial actions in the preparatory

Risk identification

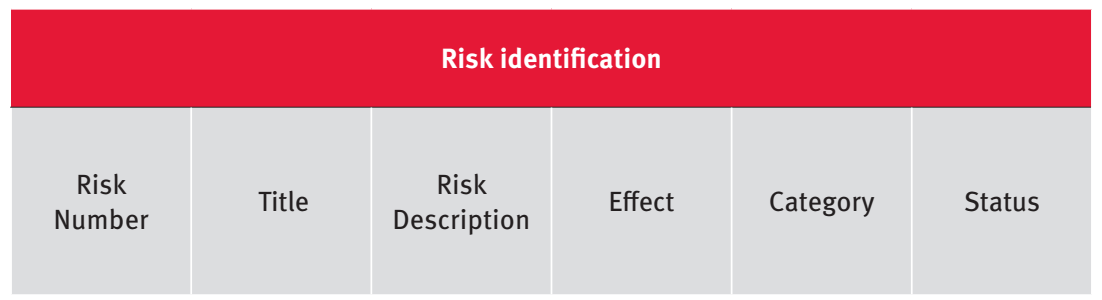

Figure 1 Methods of responses to an appropriate risk

Monitoring the risk level of certain project activities by evaluating the probability and risk categories is necessary in order to create the strategy of responses to risks. Generally, there are four types of responses to risks:

$\checkmark$ acceptance and control;

reduction;

transferring; and

$\checkmark$ avoidance.

Acceptance and control are usually carried out if the risk is within tolerable limits, because it does not require additional resources. This category of responses to risk should also be considered as the main action of risk management. Risk reduction often requires engagement of resources (and addi- stage of project completion may not be the final solution, because during the project changes occur very often, so that planned actions are not an appropriate response to the risk. Therefore, managerial actions should be implemented in response to a specific risk at a time (which may be the same as

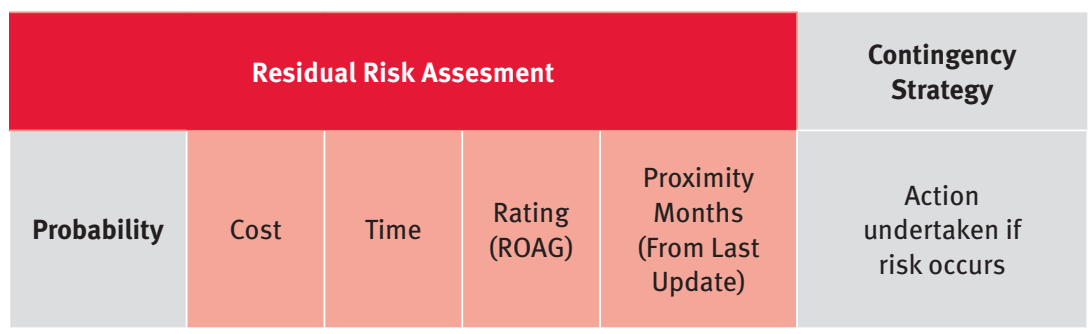

Figure 3 Procedure of remaining risks assessment and strategy of reserves actions planned in advance). At this stage risks and action holders should be designated (this is why it is important to predict delegating in the project), as well as the time determination for the conducted action.

After the implemented managerial action the risk is not usually eliminated, but it remains to exist in the project with altered probability and cost and time effects. After evaluating these parameters, as shown in Figure 3, the level (ROAG) is obtained, i.e. the level of risk at a time. General idea of that methodology is to have both cost and time risks, and to make decisions during project realization on that two parameters.

This risk level should be less than the initial risk level, which is presented at the beginning of this table. Moreover, it is important to enter the time elapsed from the last change, i.e. observation. In addition, there should be a strategy of reserves in this plan along with the anticipated actions to be implemented if a risk occurs.

The aim further analysis is to evaluate their cost and time effects and probability that they will occur based on identified risks, which tells us how large the factored cost and timing risk is, i.e. the potential reserve with which to start the project. 


\begin{tabular}{|c|c|c|c|}
\hline \multicolumn{4}{|c|}{ Risk Analysis and exposure } \\
\hline \multicolumn{4}{|l|}{ Client: } \\
\hline \multicolumn{4}{|l|}{ Project: } \\
\hline \multicolumn{4}{|c|}{ Construction / Project Manager: } \\
\hline \multicolumn{4}{|c|}{ Package / Stage / Phase } \\
\hline $\begin{array}{c}\text { Risk } \\
\text { Ref }\end{array}$ & Risk Title & Description of Risk & Management Action \\
\hline 5.1 & Water Supply & $\begin{array}{l}\text { The water supply is currently inadequate for } \\
\text { whole coastal area of Montenegro }\end{array}$ & $\begin{array}{l}\text { A new water supply contract is now underway } \\
\text { and is scheduled for completion at the end of } \\
2010 \text {, this is likely to effect the occupany of the } \\
\text { phase one buildings. Interim solutions to be } \\
\text { considerer (Herceg Novi) }\end{array}$ \\
\hline 6.4 & $\begin{array}{l}\text { Down-turn in local } \\
\text { /regional economy }\end{array}$ & $\begin{array}{l}\text { There is no guarantee that the local / regional } \\
\text { economy will continue, which may effect later } \\
\text { phases of the develoment }\end{array}$ & $\begin{array}{l}\text { AM to monitor market indicators and make } \\
\text { allowance for any down-turn in the economy }\end{array}$ \\
\hline
\end{tabular}

Figure 4 An example of risk analysis on a large construction project (project realized by paper authors)

\begin{tabular}{|c|c|c|c|c|}
\hline $\begin{array}{c}\text { Probability } \\
\text { Rating }\end{array}$ & Probability & $\begin{array}{c}\text { Risk Rating } \\
\text { Number }\end{array}$ & $\begin{array}{c}\text { Factored Risk } \\
\text { Cost }\end{array}$ & $\begin{array}{c}\text { Factored Risk } \\
\text { Duration }\end{array}$ \\
\hline $0-5$ & $40 \%$ & 8 & 800.000 .20 & 9.00 \\
\hline 2 & $60 \%$ & 3 & 30.000 .00 & 2.10 \\
\hline 3 & & & \\
\hline
\end{tabular}

Figure 6 An example of risk analysis in a large construction project

Only two risks have been processed in the table, and the descriptions of the given risk and managerial action that would eliminate or reduce risk are given in the first part of the table along with the risk itself. Both risks are classified as working (WBS) categories to make them clearer and easier to follow, and not to overlap risks.

The evaluation of cost and time consequences is graded from 1 to 5 where the gradation of monetary and time values is defined in advance. It is important to present the highest consequence level as the maximum value of cost and time consequences, because this value has a major impact on risk level. Calcu- lation of cost and time risk is based on average values.

This calculation is based on the probability of occurrence, i.e. the principle of expected monetary value is represented in this calculation. The risk level is obtained by multiplying probability of occurrence and the highest level of consequences, and the factored cost and time risks are obtained by multiplying probability of occurrence and mean values of cost and time risks.

\section{CONCLUSION}

As the PPP projects are risky from the different viewpoint of both public and private partner, due to different key success factors, risk analysis and management should be the main activity for managing these projects. Serbia is country with not many high standard infrastructure services it is very important to analyze all possible risks and to propose to the management good data for the decision making and to speed up implementation of these type of project. Bearing in mind that providing of stable financing is critical issue, especially for the big size infrastructure projects, proper risk analysis would be of great help in initiation phase, but also in further phases of project realization. That paper is general overview of possible approach on PPP project, where risks are very specific due to different goals of project stakeholders. Main contribution would be in better understanding of importance of that type of project financing.

\section{Acknowledgements}

The work reported in this paper is a part of the investigation within the research project TR 36017 supported by the Ministry for Science and Technology, Republic of Serbia. This support is gratefully acknowledged. 


\section{References}

Bing L., Akintoye A., Edwards P.J., Hardcastle C. (2005) Critical success factors for PPP/ $\mathrm{PFI}$ projects in the UK construction industry, Construction Management and Economics (June 2005) 23, pp. $459-471$

Chapman CB, Ward SC., (1997) Project risk management - processes, techniques and insights, Chichester, John Waley and Sons

Fekete R., D’Ornano F., Zatezalo M. (2007) PPPs Please, International Financial Law Review Vol 26, Issue 8

Grimsey D, Graham R (1997) PFI in the NHS, Engineering, Construction and Architectural Management 1997;4(3): pp 215-231

Li J., Patrick X.W. Zou (2011) Fuzzy AHP-Based Risk Assessment Methodology for PPP Projects, Journal of Construction Engineering and Management, December 2011;

pp 1205-1209

Patrick X.W. Zou, Shouqing W., Dongping F. (2008) A life-cycle risk management framework for PPP infrastructure projects, Journal of Financial Management of Property and Construction, Vol 13, No.2 2008, pp. 123-142

Peirson G., McBride P., (1996) Public/private sector infrastructure arrangements, CPA Communique 1996; Vol 73:pp 1-4

Rosario M. (2010) Future challenges for transport infrastructure pricing in PPP arrangements, Research in Transportation Economics 30 (2010), pp. 145-154

Smith N., Merna T., Jobling P. (2006) Managing Risk in Construction Projects, Blackwell Publishing

Solomon O.B., Akintayo O., Olusegun E.A. (2012) Critical success factors in publicprivate partnership (PPP) on infrastructure delivery in Nigeria, Journal of Facilities Management Vol. 10, No. 3 (2012), pp. 212-225

Thobami M. (1998) Private infrastructure and public risk, Finance and development; 36 (1) : pp 50-53

Zitron, J. (2004) PFI and PPP: Client and Practitioner Perspectives. Proceedings of 21st Annual Conference of the Major Projects Association, London: Major Project Association 